\title{
Old But Not Out: Social Media Use and Older Adults' Life Satisfaction
}

\section{Peter Ractham}

Thammasat Business School \& Center of Excellence in Operation and Information

Management, Thammasat University, Bangkok, Thailand

\section{Angsana A. Techatassanasoontorn}

Auckland University of Technology, New Zealand

\section{Laddawan Kaewkitipong}

Thammasat Business School, Thammasat University, Bangkok, Thailand

laddawan@tbs.tu.ac.th

\section{Abstract}

Social media has the potential to have a positive influence on older adults' quality of life. This study explores how older adults use social media and the implications of the use on their life satisfaction. A sequential mixed-method approach is used. First, focus group interviews were conducted with older adults in Thailand, and a two-step sorting procedure is employed to develop comprehensive measures of social media use activity and their life domain affiliation. Next, a field survey is used to evaluate the influence of satisfaction from social media use on domain life satisfaction and overall life satisfaction. The findings suggest that older adults integrate social media into activities in several life domains, including family, friend, community, health, consumer, education, self, leisure, and social. Satisfaction from social media use activities positively associates with domain life satisfaction in all those life domains. The comprehensive measures of social media activities enable us to extensively theorize social media use and illustrate that it has a different meaning for older adults compared with young adults.

Keywords: Life satisfaction, older adults, social media, subjective well-being.

\section{Introduction}

Information and communication technology (ICT) offers potential benefits for older adults to maintain their independence and increase their quality of life. The United Nations reported a worldwide demographic trend of an increasing share of older adults known as population aging. According to the World Health Organization, a person aged 60 years or over is considered an older adult (WHO, 2018). In 2015, the United Nations reported that the population of older adults aged 60 or over, which comprise $12.5 \%$ of the global population, is the fastest-growing population segment in the world (United Nations, 2015) and predicted to grow to around 2.1 billion in 2050, more than doubling from 962 million people in 2017 (United Nations, 2017). Therefore, population aging has immense social and economic consequences and increases the need to put resources into promoting the well-being of an increasing number of older people.

Despite their slow adoption of technology, there is growing evidence to illustrate that older adults have a positive attitude toward technology and show a willingness to incorporate technology into their lives. A study by Mitzner et al. (2010) looked at older adults' attitudes 
toward technology and reported that they used several technologies at home to facilitate different aspects of their lives and enjoyed how technologies make their life easier.

In Thailand, the latest survey by Thailand Electronic Transactions Development Agency (ETDA, 2020) revealed that the three most popular online activities among the Thai baby boomer generation, or people aged 57-75 years, were using social media, searching information, and listening to music or watching video clips. Like other countries, Thailand has experienced population aging. It is expected to become a super-aged society in 2031, with older adults aged 60 years and over accounting for more than $28 \%$ of the population (Thailand PRD, 2020).

In recent years, social media has significantly changed the way people communicate, interact, and socialize with one another. Social media ${ }^{1}$ refers to various user-driven platforms that allow users to produce and share content, thus facilitating dialogue creation and communication to a broader audience (Kapoor et al., 2018). Social media has also been used to promote social inclusion for various groups of people who might be vulnerable to be excluded from social activities (Verdegem, 2011). In particular, social media has proven to be an effective technology that helps older adults become socially included (Trentham et al., 2015). Social media include social network sites and services (e.g., Facebook, Line), video sharing sites (e.g., YouTube), blogging and microblogging (e.g., Twitter), among others. The first wave of social media users was the young people who use it as a platform of communication with their friends, allowing them to have privacy and keep "what they do online" from nosy parents (boyd, 2014) ${ }^{2}$. Over the years, the user base of social media has expanded beyond teenagers, indicating the changing landscape of users. According to the Pew Internet Report, older adults, despite being late adopters, are among the fastest-growing groups to use social media. In 2021, $45 \%$ of older adults aged 65 years or older in the U.S. used at least one type of social media, compared to 21\% in 2013 and 12\% in 2010 (Pew Research Center, 2021).

Although statistics have shown that older adults have started to embrace social media in their lives, we do not know the role of social media in their life activities and how social media use affects their lives. This is because, driven by the concern that a small percentage of older adults adopts ICT, previous studies on older adults and technology have mostly explored the agerelated digital divide to explain factors and hindrances associated with technology adoption among this age group (Chen and Chan, 2011; Hill et al., 2008; Lam and Lee, 2006; Niehaves and Plattfaut, 2014; Selwyn, 2004; Xu et al., 2020).

To address the gap in the literature, this study focuses on older adults who have adopted and used social media. We address two research questions: 1) How do older adults engage with social

\footnotetext{
${ }^{1}$ In their comprehensive review of social media studies, Kapoor et al. (2018) found that few studies defined the concept of social media. Based on the definitions used in the literature, they proposed the following definition: "[s]ocial media is made up of various user-driven platforms that facilitate diffusion of compelling content, dialogue creation, and communication to a broader audience. It is essentially a digital space created by the people and for the people, and provides an environment that is conducive for interactions and networking to occur at different levels" (p. 536)

2 danah boyd uses a lower-cased style to refer to herself. On her web site, www.danah.org, she explained that she wants "to reflect my mother's original balancing and to satisfy my own political irritation at the importance of capitalization".
} 
media to support life activities?, and 2) What is the influence of social media use on older adults' life satisfaction? Drawing on social media use and subjective well-being literature, this research aims to produce a comprehensive account of how older adults use social media and the effect of its use on their life satisfaction. Since social media is malleable and people can use it to suit their needs, it is not possible to theorize its use a priori. To elucidate social media use, we first conducted focus group interviews with older adults in Thailand and developed the social media use instrument associated with life domains. Next, we conducted a field survey to evaluate the relationship between social media use and life satisfaction.

In the following section, we review research on social media use and the subjective well-being concepts to formulate a preliminary theoretical framework for our study. Next, we present the methodology and analysis approaches followed by the discussion of results. Finally, we discuss research and practical implications, limitations, and avenues for future research.

\section{Theoretical background}

This study draws on the literature on social media use and the concept of subjective well-being with an emphasis on life satisfaction to conceptualize our preliminary research framework. We first offer a brief review of research on older adults and technology.

\subsection{Older adults and technology}

A recurring stream of research on technology and older adults aims to identify factors that explain the age-related digital divide and hindrances to technology adoption among older adults (Charness and Boot, 2009; Chen and Chan, 2011; Niehaves and Plattfaut, 2014). Some studies looked at older adults who already adopt ICT to better understand their ICT activities and impact. For example, Hur (2016) looked at the connection between objectives for participating in ICT-based activities (relationship improvement, information collection, learning, shopping, and business activities) and empowerment. He found that participating in ICT-based learning could improve older adults' empowerment. In another study, Hage et al. (2016) found that the choice of communication tools influences social connectivity among older adults who live in small rural communities. They reported that Facebook has a negative impact on connectivity with friends but not on connectivity with others in the community. However, these studies focus on selected aspects of ICT use and do not link purposes of technology use (e.g., connections) with various contexts (e.g., with friends, with family) in order to develop a precise understanding of the impact of technology.

\subsection{Social media use and influence}

The central tenet that drives the growth of users of social media sites is its design around friendship. In her book on social media, boyd (2014) highlighted four affordances that shape mediated interactions on this platform: persistence, visibility, spreadability, and searchability. Persistence means that contents and expressions on social media endure and do not expire. Interactions and contents on social media can be shared with public audiences, enabling visibility of messages and encouraging broad participation from the public. Social media often encourages people to spread information widely using easy-to-use tools such as "tags," "share," and "retweet." The spreadability of content allows individuals to share information with their circle of friends, mobilize volunteers, support political campaigns, and even spread rumors (boyd, 2014; Cogburn and Espinoza-Vasquez, 2011; Turel and Serenko, 2012). Generally, 
contents on social media are archived and searchable, allowing people to find information on any topics of interest easily.

As more people join social media, this technological environment opens up new social dynamics and transforms everyday practices for other groups of populations beyond teens and young adults. However, empirical evidence on the effects of social media use is mixed with positive (Oh et al., 2014; Valenzuela et al., 2009; Wang et al., 2014; Kim and Shen, 2020; Gaia et al., 2021) and negative consequences (Kross et al., 2013; Turel and Serenko, 2012; Rasmussen et al., 2020). A closer examination of these findings offers a more nuanced understanding of the influence of social media use. For example, Oh et al. (2014) examined social media users aged 18 to 81 . They found that the amount of supportive interaction, but not the frequency or amount of social media use, is important in establishing social support and emotional well-being, and life satisfaction. In addition, the number of friends on social media was not associated with either positive or negative affect. Gaia et al. (2021) reported a positive association between social media use and life satisfaction for older adults.

Leist (2013) looked at how older adults use social media to engage in social activities, provide and receive supports, increase feelings of control, and overcome the barriers of social exclusion. Celik et al. (2018) examined several important factors that influence life satisfaction for older adults, such as psychological effects, physical health, health status, daily life and instrumental activity. Some of the lessening life satisfaction variables for older adults include lower self-report health status, a decline in physical health, and increase in feeling depressed and feeling social withdrawal and exclusion. In particular, being active within different community activities can increase life satisfaction for older adults. Finally, in a comparative study, Kim and Shen (2020) examined the effects of engaging in different Facebook activities on older users over 50 compared to younger adults aged between 18 and 25 and found that older adults benefit less from having a large network and more from engaging in directed communication activities. This supports our proposition that older people might use social media differently from other age groups and thus require an in-depth study.

In summary, what we learn from studies in the literature is that it may be too simplistic to use proxies such as frequency, time spent on social media, and a number of friends to measure social media use and evaluate its impacts. A fine-grained, activity-level elaboration of social media use opens up opportunities to derive a more precise explanation of social media use and outcomes. For example, Turel and Serenko (2012) used the comprehensiveness of usage construct developed by Limayem et al. (2007) to measure the extent to which an individual makes use of the various functionalities of social media (e.g., posting messages and photos, reading messages sent by others, and sending gifts). They found that the range of social media functionalities that users employ provides a more robust explanation of the negative and positive outcomes of use than the amount of time spent on social media. Building on this idea, we link Turel and Serenko's (2012) functionality approach with underlying motivations in various life domains to measure social media use. For example, one may use social media to look up product information and prices to support activities in the consumer life domain. In contrast, another may use social media to search for information related to healthcare to support activities in the health life domain. We explain our approach to measure social media use in the Methodology section.

Another observation is that previous research mostly studied teens and young adults due to the concerns about the negative effects of the new technologies on their lives (boyd, 2014; 
Valenzuela et al., 2009). A review of literature on social media use by Leist (2013) discussed possible positive and negative consequences of social media use among older adults. However, their study did not empirically evaluate these consequences. Khoo and Yang (2020) studied the impacts of social media use in middle-aged and older adults on only executive functions, which is a set of domain-general cognitive control processes, but not other aspects of their lives and the impacts of their social media use on life satisfaction or well-being. Gaia et al. (2021) argued that not many studies have empirically investigated the relationship between older people's social media use and well-being. Although their study looked at the relationship between social media use and life satisfaction, they did not investigate how older adults use social media. Since older adults are one of the fast-growing users of social media, we need to have a better understanding of how they use social media and the implications of its use on their lives, which is the aim of this study.

\subsection{Subjective well-being: Life satisfaction}

We draw on subjective well-being literature to theorize outcome variables associated with social media use. Subjective well-being refers to how people feel about their lives (Diener, 1984; Kahneman and Krueger, 2006). This concept constitutes three interrelated components: people's feelings, domain life satisfaction, and overall life satisfaction. Although all three components are important to evaluate people's subjective experiences, research suggests that domain life satisfaction and overall life satisfaction can portray a state of people's lives (Diener et al., 2013). Life satisfaction allows people to reflect and assess how they feel about many areas of their lives, such as health, social activities, work, and family, among others.

In this study, we draw on the concept of life satisfaction (Diener, 1984) to theorize the impact of social media use. Life satisfaction is a global assessment of the quality of life according to a person's own criteria. Thus, the extent of life satisfaction may depend on one's circumstances and what the person sets as the standard of a good life for himself or herself. This study uses the life domain approach to explain the influence of social media use on life satisfaction. The tenet of this approach is that overall life satisfaction is shaped by reported satisfaction with various life domains. An individual's life can be segmented into several life domains (Andrews and Withey, 1976). Some of the key ones are family, friends, community, health, leisure, and work (Diener and Diener, 1995; Easterlin, 2006; Headey et al., 1991; Oishi et al., 1999; van Praag et al., 2003).

To establish the link between domain life satisfaction and overall life satisfaction associated with social media use, we first develop an account of social media use at an activity level and subsequently evaluate the impact of social media use on life satisfaction. Our activity-level measurement of social media use is aligned with Scheepers and Middleton's (2013) framework on the study of personal ICTs. This line of thinking highlights an individual frame of reference to use personal ICTs "to support typical routines across the multiple contexts of his or her life" (p. 382). In addition, our approach answers the call from other researchers to find an alternative paradigm that treats users as active participants in the ICT use experience to develop a comprehensive understanding of their ICT use. This new paradigm is appropriate to study several emerging ICT such as blogs, social media sites, virtual worlds, and mobile services that support diverse user goals and values. For example, Jung's (2014) investigation of different values that users pursue with smartphones pays attention to "what users actually do with the technology rather than which factors affect user adoption of a given technology" (p. 313). 
Similar to personal ICTs and other emerging ICT, social media use span multiple boundaries such as home, work, and leisure. In addition, different individuals have the freedom to choose to engage with social media to support their idiosyncratic needs. For example, one person may use social media to keep in touch with old friends, and another person may choose to use social media for entertainment, searching for and sharing health information, and volunteering. We use domains of life (e.g., family, friend, community, health) to organize social media use to give participants a frame of reference to describe their social media use that spans multiple contexts and multiple purposes and allow us to develop a better understanding of the meaning of social media in their lives. The findings will also enable us to identify salient domains in which social media use has a strong contribution to people's overall life satisfaction.

\subsection{Preliminary theoretical model}

Our preliminary theoretical framework is built on the broad theorizing of the life satisfaction process (Campbell et al., 1976; Diener et al., 1999). The theoretical logic of this process is that overall life satisfaction is derived from one's satisfaction with various life domains. Reported satisfaction in each life domain, in turn, reflects the extent to which one's goals and needs in that life domain are met through domain-related activities. For example, ill health can make a person feel bad and unhappy. It is likely to negatively influence how he or she assesses his or her overall life satisfaction (Diener, 1984).

In this study, we extend the life satisfaction process logic to examine the role of social media in people's lives. Social media is applicable and useful for various activities across different life domains. For example, Choi et al. (2014) show how social media can be appropriated for health promotion. Social media is a useful platform for people to share their opinions regarding products and services (Turel and Serenko, 2012). Park et al. (2009) found that individuals use Facebook for various purposes, such as socializing, status-seeking, entertainment, and information seeking. Similarly, Xu et al. (2012) reported the relationship between affection, coordination, entertainment, immediate access, relaxation gratifications, and social media use. However, previous research on social media use has mostly focused on youth and young adults. The results may be less applicable to older adults due to different lifestyles and purposes of use. For example, Gatto and Tak (2008) suggest that older adults' usage of ICT applications are different from the younger generation due to physical limitation, learning ability, and access to technology.

Based on these arguments, we extend the life satisfaction process reasoning to argue that satisfaction from social media use across life activities shapes domain life satisfaction, which, in turn, influences overall life satisfaction. It is important to emphasize that the theoretical model offers a process logic to guide this study's empirical inquiry. The precise theoretical logic of the relationship between social media use, domain life satisfaction, and overall life satisfaction is inductively analyzed and emerged from the data. Figure 1 presents the preliminary theoretical model to illustrate the process of how social media use influences life satisfaction. 


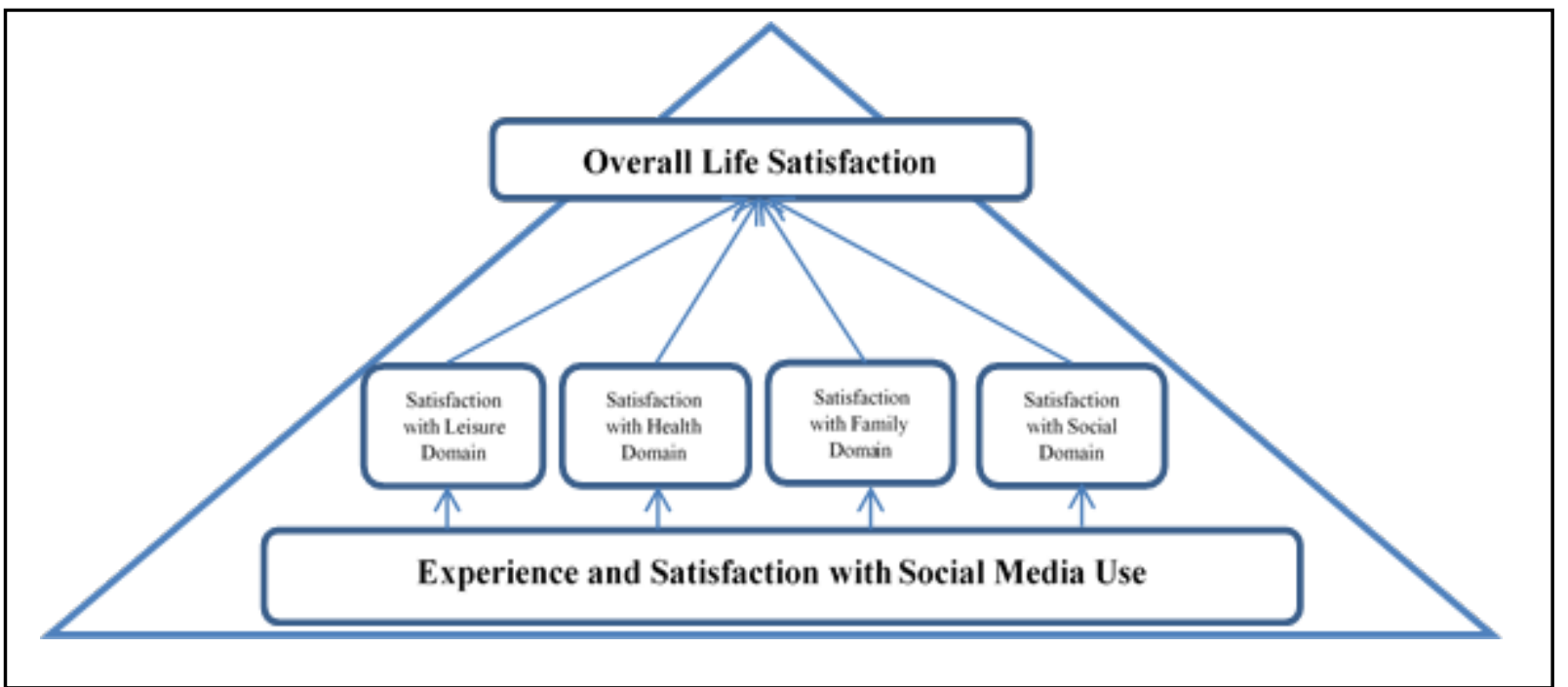

Figure 1. A preliminary model of social media use and impacts on life satisfaction

Note: The diagram uses the leisure, health, family, and social life domains to illustrate the influence of social media use on life satisfaction. In an empirical evaluation, the life domains are inductively analyzed and emerged from the data on older adults' use of social media in their daily lives.

\section{Methodology and analysis}

We use a sequential mixed method approach in our research inquiry. The inquiry constitutes the use of focus group interviews to develop a comprehensive account of social media use, followed by a field survey to evaluate the relationship between social media use and life satisfaction through domain life satisfaction. Table 1 presents how we apply Venkatesh et al. 's (2013) mixed-method design guidelines in this study with two purposes in mind: completeness and developmental. In the context of our research, completeness refers to the usefulness of a mixed-methods design to obtain a complete picture of a phenomenon, which is to develop a substantive theory ${ }^{3}$ of social media use and its impact on older adults' lives. Developmental refers to the efficacy of a mixed-method design to use extensive measures of social media use across life domains from a qualitative method to evaluate the relationship between social media use and life satisfaction using a quantitative method.

\begin{tabular}{|l|l|}
\hline Guideline & Application in this study \\
\hline $\begin{array}{l}\text { Decide on the appropriateness of a } \\
\text { mixed-methods approach }\end{array}$ & $\begin{array}{l}\text { The state-of-the-art research on social media use and its consequences } \\
\text { is limited to young adults, and the findings are inconclusive with a mix } \\
\text { of positive and negative outcomes. This gives us an opportunity to } \\
\text { provide a holistic understanding of social media use and its impacts. }\end{array}$ \\
\hline $\begin{array}{l}\text { Develop a strategy for mixed methods } \\
\text { research design }\end{array}$ & $\begin{array}{l}\text { The goal of this study is to develop rich insights into older adults' social } \\
\text { media use in various life domains and evaluate its impacts on life } \\
\text { satisfaction. Since social media is a multi-purpose technology and users } \\
\text { choose to use the technology that best serves their needs, there is a need } \\
\text { to use a qualitative method (focus groups) to develop a comprehensive } \\
\text { understanding of social media use. A quantitative approach (survey) is } \\
\text { then used to evaluate the impact of social media use on older adults' } \\
\text { life satisfaction through domain life satisfaction. }\end{array}$ \\
\hline
\end{tabular}

\footnotetext{
${ }^{3}$ Substantive theory refers to theory that constitutes concepts and their relations to explain a phenomenon or a substantive area of inquiry (Glaser and Strauss, 1967; Urquhart et al., 2010; Venkatesh et al., 2013). In this study, the mixed method approach enables us to develop in-depth understanding of social media use and its meaning to people's lives through life satisfaction outcomes.
} 


\begin{tabular}{|l|l|}
\hline $\begin{array}{l}\text { Develop a strategy for analyzing } \\
\text { mixed methods data }\end{array}$ & $\begin{array}{l}\text { A comprehensive account and validated instrument of social media } \\
\text { use and associated life domains is derived from focus group interviews } \\
\text { and two-step sorting procedures. The validated social media use items } \\
\text { are incorporated into a survey along with measures of life satisfaction } \\
\text { and domain life satisfaction. Measurement model validity is assessed } \\
\text { before the evaluation of the structural model using PLS-SEM. }\end{array}$ \\
\hline $\begin{array}{l}\text { Draw meta-inferences from mixed } \\
\text { methods results }\end{array}$ & $\begin{array}{l}\text { This study develops a meta-inference or substantive theory of social } \\
\text { media use and its impact on older adults' life satisfaction that identifies } \\
\text { social media use activities in relation to life domains that are salient to } \\
\text { life satisfaction. }\end{array}$ \\
\hline
\end{tabular}

Table 1. Mixed methods research guidelines

We inductively develop precise measurements of social media use from our study participants by following a two-phased approach. In the first phase, we developed a comprehensive account and validated instrument of social media use and associated life domains through focus group interviews and sorting procedures, respectively. In the second phase, we used the social media use instrument from the first phase along with validated measures of the domain and overall life satisfaction to examine the influence of social media use on older adults' life satisfaction.

\subsection{Phase 1: Development of social media use measures}

We conducted initial focus group interviews with two groups of 15 older adults (10 females and 5 males). Then, the members from these first two groups referred us to two groups of retired professionals ( 5 females and 2 males) and retired civil servants ( 3 females and 3 males). These first four focus group interviews were conducted in Bangkok, Thailand. After that, we identified those who are social media users outside of Bangkok. We expanded our interviews to all the regions in Thailand through the means of convenience sampling by making posts on Facebook and sending private messages to various groups of NGOs, Associations of Senior Citizens, and Associations of Retired Civil Servants. In addition, we also contacted potential participants by phone and through social media channels. Overall, we conducted 24 group interviews with 124 older adults in 20 provinces across Thailand. The focus group interviewees' profiles are shown in Table 2.

\begin{tabular}{|l|c|c|}
\hline \multicolumn{2}{|c|}{ Number of Interviewees } & Percent \\
\hline Gender & 54 & 43.5 \\
\hline Male & 70 & 56.5 \\
\hline Female & & 41.4 \\
\hline Regions & 51 & 16.1 \\
\hline Central (Including Bangkok) & 20 & 14.4 \\
\hline North & 18 & 28.1 \\
\hline South & 35 & 67.7 \\
\hline Northeast & \multicolumn{2}{|}{} \\
\hline Age & 84 & 24.2 \\
\hline $60-65$ years old & 30 & 8.1 \\
\hline 66 -70 years old & 10 & 7.2 \\
\hline 70 -75 years old & & 12.9 \\
\hline Education level & 9 & 16.1 \\
\hline Below high school & 16 & 60.4 \\
\hline High school & 20 & \\
\hline Technical college & 75 & \\
\hline Bachelor Degree & & \\
\hline
\end{tabular}




\begin{tabular}{|c|c|c|}
\hline & Number of Interviewees & Percent \\
\hline Master or Ph.D. & 4 & 3.2 \\
\hline \multicolumn{3}{|l|}{ Monthly income } \\
\hline 10,001 - 20,000 Baht & 30 & 24.1 \\
\hline 20,001 - 30,000 Baht & 65 & 52.5 \\
\hline More than 30000 Baht & 29 & 23.4 \\
\hline \multicolumn{3}{|l|}{ Social media use frequency } \\
\hline Everyday & 90 & 72.7 \\
\hline 5 - 6 days per week & 10 & 8.0 \\
\hline 3 - 4 days per week & 11 & 8.8 \\
\hline 1 - 2 days per week & 6 & 4.8 \\
\hline 1 day fortnightly & 5 & 4.0 \\
\hline Less than 1 day fortnightly & 2 & 1.7 \\
\hline \multicolumn{3}{|l|}{ Hours per day } \\
\hline Less than 1 hour & 10 & 8.0 \\
\hline $1-3$ hours & 35 & 28.4 \\
\hline $3-5$ hours & 70 & 56.6 \\
\hline More than 5 hours & 9 & 7.2 \\
\hline \multicolumn{3}{|c|}{ Social media platforms used (can choose more than one choice) } \\
\hline Facebook & 101 & 81.4 \\
\hline YouTube & 101 & 81.4 \\
\hline Line Chat & 120 & 96.7 \\
\hline Instagram & 35 & 28.2 \\
\hline Blog & 4 & 3.2 \\
\hline Others & 3 & 2.4 \\
\hline \multicolumn{3}{|l|}{ Work status } \\
\hline Full-time & 18 & 14.5 \\
\hline Part-time & 24 & 19.3 \\
\hline Retired & 82 & 66.2 \\
\hline \multicolumn{3}{|l|}{ Living condition } \\
\hline Live by themselves & 11 & 8.2 \\
\hline Live with family or relatives & 89 & 71.8 \\
\hline Live with friend(s) & 2 & 1.8 \\
\hline Live with spouse & 20 & 16.4 \\
\hline Others & 2 & 1.8 \\
\hline
\end{tabular}

Table 2. Focus group interviewee profiles

Each focus group interview session was between $60-90$ minutes. During the focus group sessions, we asked participants to share information using three open-ended questions: "How did you start using social media and why?" (Goal: to obtain background information about their lifestyles) "What social media do you frequently use and why?" (Goal: to understand areas of social media use) and "What do you usually use social media for and how do you use it to support your lifestyle?) (Goal: to identify social media use, associated life domains, and the perceived influence of social media use on domain life satisfaction).

We audio-taped and transcribed all the interview sessions. The 108-page transcripts were used to identify social media use and associated life domains. Based on the life domain definitions from the literature, the two authors independently coded social media use and their associated life domains, according to the three key pieces of data from the focus group interviews. These data cover the purposes of social media use, how it was used, and the types of social media platforms. For example, "I use Facebook to contact my daughter who lives in America." was 
coded as "contact family" (social media use) that is associated with the "family life domain" (life domain). Disagreements on social media use or life domains were resolved through discussion between the two coders. Overall, a total of 48 different social media use in ten life domains were identified. They were family, friend, community, leisure, health, self, social, education, consumer, and work life domains. These life domains and selected interview excerpts are shown in Table 3.

\begin{tabular}{|c|c|c|c|c|}
\hline Life domain & Goal & Context & Type & Interview excerpts \\
\hline Family & Stay connected & $\begin{array}{l}\text { Live separately from the } \\
\text { family }\end{array}$ & $\begin{array}{l}\text { Facebook, } \\
\text { Skype, and } \\
\text { Line Chat } \\
\text { App } \\
\end{array}$ & $\begin{array}{l}\text { "I feel that I am closer to } \\
\text { my family because of } \\
\text { social media." }\end{array}$ \\
\hline Friend & Nurture friendship & $\begin{array}{l}\text { Reconnect with old } \\
\text { friends }\end{array}$ & $\begin{array}{l}\text { Facebook } \\
\text { and Line } \\
\text { Chat App }\end{array}$ & $\begin{array}{l}\text { "I found many old friends } \\
\text { from high school and } \\
\text { college." }\end{array}$ \\
\hline Community & $\begin{array}{l}\text { Community } \\
\text { involvement }\end{array}$ & $\begin{array}{l}\text { Participate or invite } \\
\text { others to participate in } \\
\text { community services }\end{array}$ & Facebook & $\begin{array}{l}\text { "I volunteered for many } \\
\text { community events." }\end{array}$ \\
\hline Leisure & Pass the time & Wait in queues & $\begin{array}{l}\text { Line Chat } \\
\text { App and } \\
\text { YouTube }\end{array}$ & $\begin{array}{l}\text { "I usually use Line Chat } \\
\text { with my friends when I'm } \\
\text { waiting in line." }\end{array}$ \\
\hline Health & $\begin{array}{l}\text { Health } \\
\text { improvement }\end{array}$ & $\begin{array}{l}\text { Learn about illness and } \\
\text { alternative medicines }\end{array}$ & $\begin{array}{l}\text { YouTube } \\
\text { and Blog }\end{array}$ & $\begin{array}{l}\text { "I learned about herbal } \\
\text { medicines from YouTube." }\end{array}$ \\
\hline Self & $\begin{array}{l}\text { Self- } \\
\text { accomplishment }\end{array}$ & $\begin{array}{l}\text { Want to show off self- } \\
\text { accomplishment }\end{array}$ & Facebook & $\begin{array}{l}\text { "I like to show my } \\
\text { vacation pictures on social } \\
\text { media." }\end{array}$ \\
\hline Social & $\begin{array}{l}\text { Expand social } \\
\text { network }\end{array}$ & $\begin{array}{l}\text { Find new friends and } \\
\text { those who share similar } \\
\text { interests }\end{array}$ & $\begin{array}{l}\text { Facebook } \\
\text { and Blog }\end{array}$ & $\begin{array}{l}\text { "I use social media to find } \\
\text { a new interest group like } \\
\text { the bicycle club." }\end{array}$ \\
\hline Education & Learn new things & $\begin{array}{l}\text { Learn about cooking and } \\
\text { traveling }\end{array}$ & YouTube & $\begin{array}{l}\text { "I usually learn about new } \\
\text { recipes on YouTube." }\end{array}$ \\
\hline Work & $\begin{array}{l}\text { Achieve work } \\
\text { related activities }\end{array}$ & $\begin{array}{l}\text { Communicate with } \\
\text { colleagues/customers }\end{array}$ & $\begin{array}{l}\text { Facebook } \\
\text { and Line } \\
\text { Chat App }\end{array}$ & $\begin{array}{l}\text { "I use Facebook and/or } \\
\text { Line Chat to contact my } \\
\text { colleagues or customers } \\
\text { quite often." }\end{array}$ \\
\hline Consumer & Save money & Want to save money & Facebook & $\begin{array}{l}\text { "I search for deals to save } \\
\text { money on social media." }\end{array}$ \\
\hline
\end{tabular}

Table 3. Ten life domains and selected interview scripts

Next, we used two-step sorting procedures (Moore and Benbasat, 1991) to develop the social media use scale and assess the reliability and construct validity of the social media use items. As suggested by Petter et al. (2007, p. 639), "[a] two-step Q-sort may be one of the best methods to assess content validity for formative constructs." Several studies in IS have used the term Qsorts to refer to these sorting procedures in the instrument development process (Chang and King, 2005; Gerow et al., 2015). However, Thomas and Watson (2002, p. 153) strongly argue that the validation sorts proposed by Moore and Benbasat (1991) and subsequently used by many IS researchers "should be labeled something other than 'Q-sorts' to reduce confusion." Therefore, in this study, we use the term sorting procedures instead of Q-sorts to refer to the procedure we followed to establish content and construct validity.

In the first round, four participants who were not involved with the project were asked to examine and sort 48 social media use items into the ten life domains identified from the focus group data. If the participants believed that a particular social media use item did not match 
any of the ten life domains, they could categorize this item as part of the "Ambiguous or Unclear" group. All items were presented on index cards for convenience with the sorting process. We checked the level of agreement among participants using Fleiss's Kappa, which has an average value of $0.64(p<.001)$, suggesting substantial agreement among them. After the sorting procedure, the authors and the four participants discussed and clarified the ambiguous items. A few items were merged together, and the number of social media use items was reduced to 46 items. In the second round, we asked two different participants to sort the modified social media use items from the first round into life domains as they saw fit. The two participants created eight and twelve life domains, respectively. The calculated Fleiss's Kappa was $0.45(p<.001)$, suggesting moderate agreement between the two participants. The most ambiguous domains were the community and social life domains. The authors and the two participants discussed and agreed that these two life domains should remain separate. We also agreed that some of the similar social media use items should be merged. The final number of items was reduced to 44 (see these items in Table 5 in the Results section). Based on the results from our coding and sorting procedures, we concluded that social media use measures have content, convergent, and discriminant validity.

\subsection{Phase 2: Examining the influence of social media use on older adults' life satisfaction}

In this phase, we used a field survey to evaluate the influence of satisfaction from social media use on domain life satisfaction, which, in turn, shapes overall life satisfaction. We used three groups of constructs in the questionnaire: satisfaction from social media use, domain life satisfaction, and overall life satisfaction. Social media use items constitute 44 items from the scale developed in Phase 1. Domain life satisfaction is a single-item scale drawn from Diener and Diener (1995). The overall life satisfaction construct has five validated items from Diener et al. (1985).

We measured all three constructs with the 7-point Likert scale. The scales of satisfaction from social media use are anchored with 1 - "strongly dissatisfied" to 7 - "strongly satisfied", while a scale of 0 is used for "never used." The domain life satisfaction and overall life satisfaction scales were measured from 1 - "strongly disagree" to 7 - "strongly agree." The survey instrument was pretested with 12 older adults. Some modifications were made to clarify a few social media use items.

To draw survey participants from diverse and different economic and educational backgrounds, we distributed 600 questionnaires to older adults from all four regions in Thailand. During the three months of the field survey, one of the authors and three research assistants mailed the survey to participants and traveled to various parts of Thailand to distribute, administer, and collect the questionnaires. In total, we received 341 questionnaires back from both face-to-face meetings and postal mail. After excluding cases with missing data or incomplete responses, 337 surveys were retained for data analysis. Overall, there are 139 male and 198 female respondents, and approximately 75\% of participants were between 60-65 years old. More than $70 \%$ of respondents are retirees. Most (64\%) are married and live with their spouse. Close to $65 \%$ have a college degree, and about $48 \%$ earn a monthly income of between $\$ 1000$ - $\$ 3000$, which is considered to be in the middle-income bracket in Thailand. Respondents have an average of 7 years of computer experience and 3.5 years of social media experience. Sixty percent of the respondents have used social media for between 2-5 years. More than $53 \%$ of the respondents use social media on a daily basis, while about $29 \%$ use it 3- 
6 days a week. Facebook (69\%) and Line chat (73\%) are popular social media platforms that respondents use. Respondent profiles are shown in Table 4.

\begin{tabular}{|c|c|c|}
\hline & Number of respondents & Percent \\
\hline \multicolumn{3}{|l|}{ Gender } \\
\hline Male & 139 & 41.2 \\
\hline Female & 198 & 58.8 \\
\hline \multicolumn{3}{|l|}{ Age } \\
\hline $60-65$ years old & 253 & 75.1 \\
\hline $66-70$ years old & 53 & 15.7 \\
\hline $70-75$ years old & 26 & 7.7 \\
\hline $76-80$ years old & 5 & 1.5 \\
\hline \multicolumn{3}{|l|}{ Marital status } \\
\hline Single & 46 & 13.6 \\
\hline Widow & 54 & 16.0 \\
\hline Married & 216 & 64.1 \\
\hline Divorced or Separated & 21 & 6.2 \\
\hline \multicolumn{3}{|l|}{ Education level } \\
\hline Below high school & 41 & 12.2 \\
\hline High school & 43 & 12.8 \\
\hline Technical college & 35 & 10.4 \\
\hline Bachelor Degree & 160 & 47.5 \\
\hline Master or Ph.D. & 57 & 16.9 \\
\hline \multicolumn{3}{|l|}{ Monthly income } \\
\hline Less than 2000 Baht & 9 & 2.7 \\
\hline $2001-10,000$ Baht & 93 & 27.3 \\
\hline 10,001 -20,000 Baht & 78 & 23.1 \\
\hline 20,001 -30,000 Baht & 83 & 24.6 \\
\hline More than 30000 Baht & 74 & 22.0 \\
\hline \multicolumn{3}{|l|}{ Social media use frequency } \\
\hline Everyday & 180 & 53.4 \\
\hline 5 - 6 days per week & 48 & 14.2 \\
\hline 3 - 4 days per week & 50 & 14.8 \\
\hline 1 - 2 days per week & 35 & 10.4 \\
\hline 1 day fortnightly & 9 & 2.7 \\
\hline Less than 1 day fortnightly & 15 & 4.5 \\
\hline \multicolumn{3}{|l|}{ Hours per day } \\
\hline Less than 1 hour & 74 & 22.0 \\
\hline $1-3$ hours & 161 & 47.8 \\
\hline $3-5$ hours & 86 & 25.5 \\
\hline More than 5 hours & 16 & 4.7 \\
\hline \multicolumn{3}{|c|}{ Social media platforms used (can choose more than one choice) } \\
\hline Facebook & 231 & 68.5 \\
\hline YouTube & 138 & 40.9 \\
\hline Line Chat & 246 & 73.0 \\
\hline Instagram & 31 & 9.2 \\
\hline Blog & 5 & 1.5 \\
\hline Others & 5 & 1.5 \\
\hline \multicolumn{3}{|l|}{ Work status } \\
\hline Full-time & 45 & 13.4 \\
\hline Part-time & 44 & 13.1 \\
\hline Retired & 246 & 73.0 \\
\hline
\end{tabular}




\begin{tabular}{|l|c|c|}
\hline & Number of respondents & Percent \\
\hline Living condition & 35 & 10.4 \\
\hline Live by themselves & 124 & 36.8 \\
\hline Live with family or relatives & 2 & 0.6 \\
\hline Live with friend(s) & 172 & 51.0 \\
\hline Live with spouse & 4 & 1.2 \\
\hline Others & & \\
\hline
\end{tabular}

Table 4. Respondent profiles

Next, we conducted Partial Least Squares Structural Equation Modeling (PLS-SEM) to evaluate the influence of satisfaction with social media use on domain life satisfaction and the influence of domain life satisfaction on overall life satisfaction. We decided to use PLS-SEM because our data did not have a multivariate normal distribution. Mardia's coefficient is higher than 10, indicating non-normality. PLS does not have a strict requirement for data distribution (Hair et al., 2013). Our sample size of 337 satisfies the minimal sample for PLS-SEM, which should be ten times the largest number of structural paths pointing to any latent construct in the model. In our model, the largest number of paths pointing to overall life satisfaction is 10 .

Finally, our model has both formative constructs (satisfaction from social media use) and reflective constructs (overall life satisfaction). Since each formative construct (e.g., satisfaction from social media use in the family domain) is linked to only one effect construct (family life satisfaction), the model is underidentified and does not allow the estimation of the paths from the formative indicators to the construct and the variance of the error term in the covariancebased SEM (Diamantopoulos, 2011). Therefore, we believe that PLS-SEM is an appropriate analysis method.

\section{Results}

We first present the respondents' patterns of social media use and levels of satisfaction. Next, we report the evaluation of the influence of satisfaction from social media use on domain life satisfaction and overall life satisfaction.

Table 5 presents the patterns of social media use and the respondents' levels of satisfaction. From the analysis, the participants showed satisfaction with social media use in all ten life domains. The top ten social media use activities are in the family, health, leisure, consumer, self, and friend domains. Our finding is consistent with that of Chou et al. (2009), who argued that social media has the potential for health communication and that an increasing number of older adults are likely to use social media for such purpose. The high degree of satisfaction from social media use for familial purposes among older adults is not surprising. It was reported in Croll (2006) that Asians have a strong commitment to family, and relationships within the family are important to their well-being. In addition to activities related to health and family domains, older adults also use social media for leisure purposes, such as taking photographs and posting pictures, playing games, and browsing social media to pass the time.

While older adults reported social media use and satisfaction with their use in the family, health, and leisure domains, they are least satisfied with the use of social media to form new social relationships. Although social media have been used mostly by adolescents and young adults to find new friends, older adults voice their concern about using social media to establish new relationships due to the lack of trust and safety concerns. This is in line with arguments in prior research that older adults have a strong emotional investment with family 
members and established friends (Chen and Chan, 2011; Hur, 2016). In addition, trust is an important factor affecting information sharing and new relationship development in an online setting, particularly for older adults (Choi et al., 2014).

\begin{tabular}{|c|c|c|c|c|}
\hline Life domain & Social media use & $\begin{array}{c}\text { Never } \\
\text { use }\end{array}$ & Mean & S.D. \\
\hline \multirow[t]{4}{*}{ Family } & $\begin{array}{l}\text { Use social media to discuss, share pictures and follow family } \\
\text { members' activities }\end{array}$ & $2.4 \%$ & 5.77 & 1.55 \\
\hline & Use social media to check on family members' safety & $8.3 \%$ & 5.18 & 1.99 \\
\hline & Use social media to tell family about my whereabouts & $11.3 \%$ & 4.90 & 2.14 \\
\hline & $\begin{array}{l}\text { Use social media to connect with family members who live far } \\
\text { away }\end{array}$ & $4.7 \%$ & 5.62 & 1.73 \\
\hline \multirow[t]{5}{*}{ Friend } & $\begin{array}{l}\text { Use social media to send electronic greeting cards on special } \\
\text { occasions }\end{array}$ & $8.0 \%$ & 5.30 & 1.96 \\
\hline & $\begin{array}{l}\text { Use social media to communicate with friends and follow their } \\
\text { activities }\end{array}$ & $4.5 \%$ & 5.56 & 1.63 \\
\hline & Use social media to share safety news with friends & $8.9 \%$ & 5.01 & 1.98 \\
\hline & Use social media to arrange get-together with friends & $6.2 \%$ & 5.34 & 1.85 \\
\hline & Use social media to rediscover old friends & $12.2 \%$ & 4.87 & 2.17 \\
\hline \multirow[t]{2}{*}{ Work } & Use social media to distribute work-related news & $9.5 \%$ & 5.02 & 1.98 \\
\hline & Use social media to communicate with customers & $20.5 \%$ & 4.10 & 2.39 \\
\hline \multirow[t]{5}{*}{ Community } & $\begin{array}{l}\text { Use social media to distribute and receive community/provincial } \\
\text { related news and activities }\end{array}$ & $8.6 \%$ & 5.07 & 1.99 \\
\hline & $\begin{array}{l}\text { Use social media to distribute news related to volunteer activities } \\
\text { within own community }\end{array}$ & $11.0 \%$ & 5.05 & 4.41 \\
\hline & $\begin{array}{l}\text { Use social media to connect between community leaders and } \\
\text { members }\end{array}$ & $10.7 \%$ & 4.70 & 2.08 \\
\hline & $\begin{array}{l}\text { Use social media to receive news from central government and } \\
\text { distribute them to community members }\end{array}$ & $18.4 \%$ & 4.26 & 2.33 \\
\hline & $\begin{array}{l}\text { Use social media to distribute charitable news to community } \\
\text { members. }\end{array}$ & $11.9 \%$ & 4.76 & 2.16 \\
\hline \multirow[t]{4}{*}{ Health } & $\begin{array}{l}\text { Use social media to search for information related to healthcare, } \\
\text { exercise and healthy food }\end{array}$ & $1.8 \%$ & 5.60 & 1.43 \\
\hline & $\begin{array}{l}\text { Use social media to consult friends, relatives or health experts on } \\
\text { health-related issues }\end{array}$ & $9.8 \%$ & 4.91 & 1.99 \\
\hline & $\begin{array}{l}\text { Play social media games to do brain exercise to prevent memory } \\
\text { loss }\end{array}$ & $3.6 \%$ & 5.73 & 1.53 \\
\hline & $\begin{array}{l}\text { Use social media to share information about health and } \\
\text { medicines }\end{array}$ & $5.6 \%$ & 5.41 & 1.72 \\
\hline \multirow[t]{4}{*}{ Consumer } & Use social media to look up product information and price & $9.2 \%$ & 5.03 & 1.95 \\
\hline & Use social media to follow news from favorite shops & $13.1 \%$ & 4.59 & 2.11 \\
\hline & Use social media to make phone or video calls to save money & $3.9 \%$ & 5.72 & 1.67 \\
\hline & Use social media to exchange product information with others & $19.3 \%$ & 4.13 & 2.30 \\
\hline \multirow[t]{3}{*}{ Education } & $\begin{array}{l}\text { Use social media to learn new things such as stock trading, } \\
\text { English language and new technology }\end{array}$ & $3.6 \%$ & 5.42 & 1.69 \\
\hline & Use social media to find useful information such as DIY projects & $10.4 \%$ & 4.66 & 2.14 \\
\hline & Use social media to find answers from experts & $8.9 \%$ & 5.03 & 1.99 \\
\hline \multirow[t]{3}{*}{ Self } & $\begin{array}{l}\text { Use social media to post pictures of what I accomplish with my } \\
\text { hobbies }\end{array}$ & $4.2 \%$ & 5.57 & 1.66 \\
\hline & $\begin{array}{l}\text { Use social media to share personal thoughts and opinions with } \\
\text { people who share similar interests }\end{array}$ & $6.2 \%$ & 5.18 & 1.78 \\
\hline & Use social media to read dharma to lift up my spiritual self & $5.9 \%$ & 5.00 & 1.78 \\
\hline
\end{tabular}




\begin{tabular}{|c|c|c|c|c|}
\hline Life domain & Social media use & $\begin{array}{c}\text { Never } \\
\text { use }\end{array}$ & Mean & S.D. \\
\hline & $\begin{array}{l}\text { Use social media to share stories, pictures and video clips such as } \\
\text { funny gags and classical music }\end{array}$ & $4.5 \%$ & 5.41 & 1.65 \\
\hline & Use social media to post pictures of the places I travelled to & $6.2 \%$ & 5.57 & 1.80 \\
\hline & Use social media to share sermons with others & $13.1 \%$ & 4.73 & 2.19 \\
\hline & $\begin{array}{l}\text { Use social media to build my self-image showing that I am a part } \\
\text { of a digital society }\end{array}$ & $8.6 \%$ & 5.03 & 1.96 \\
\hline & $\begin{array}{l}\text { Use social media to share my life stories or other interesting } \\
\text { stories with people who follow my channels }\end{array}$ & $13.1 \%$ & 4.75 & 2.18 \\
\hline \multirow[t]{6}{*}{ Leisure } & Use social media to manage loneliness & $2.1 \%$ & 5.86 & 1.46 \\
\hline & $\begin{array}{l}\text { Use social media for entertainment purposes (movie, music, } \\
\text { game and novel) }\end{array}$ & $3.3 \%$ & 5.48 & 1.68 \\
\hline & Use social media to follow celebrities & $7.4 \%$ & 4.88 & 1.87 \\
\hline & Use social media to find information about interesting hobbies & $3.6 \%$ & 5.36 & 1.65 \\
\hline & $\begin{array}{l}\text { Use social media to organize trips (accommodations, restaurants } \\
\text { and travel routes) }\end{array}$ & $5.0 \%$ & 5.18 & 1.71 \\
\hline & Use social media to find interesting pictures & $8.9 \%$ & 5.07 & 2.05 \\
\hline \multirow[t]{3}{*}{ Social } & Use social media to find new friends & $12.5 \%$ & 4.63 & 2.17 \\
\hline & Use social media to join different groups to share experiences & $7.1 \%$ & 5.14 & 1.78 \\
\hline & $\begin{array}{l}\text { Use social media to join different groups to chat, socialize with } \\
\text { others who share similar interests, such as politics }\end{array}$ & $9.2 \%$ & 4.89 & 1.98 \\
\hline
\end{tabular}

Table 5. Social media use and respondents' level of satisfaction

We also performed a break-down analysis of social media use by age groups (see Table 6). Overall, all age groups shared similar choices of social media platforms that they used. In particular, Line chat and Facebook were popular social media platforms across all age groups. This is in line with the statistics presented in Table 5 that older adults used social media mostly for connecting with friends and family. Interestingly, Instagram and Blog were used by a smaller group of older adults.

\begin{tabular}{|c|c|c|c|c|c|c|}
\hline \multirow{2}{*}{ Age } & \multicolumn{6}{|c|}{ Social medial platform used } \\
\hline & Facebook & YouTube & Line chat & Instagram & Blog & Others \\
\hline 60 - 65 years old (253 persons) & 171 & 107 & 183 & 27 & 3 & 4 \\
\hline 66 - 70 years old (53 persons) & 40 & 22 & 43 & 4 & 1 & 1 \\
\hline $70-75$ years old ( 26 persons) & 17 & 9 & 17 & 0 & 1 & 0 \\
\hline $76-80$ years old ( 5 persons) & 3 & 0 & 3 & 0 & 0 & 0 \\
\hline Total & 231 & 138 & 246 & 31 & 5 & 5 \\
\hline
\end{tabular}

Table 6. Social media platform used by different age groups of the older adults

\subsection{Measurement model}

The measurement model has one reflective construct (overall life satisfaction) and ten formative constructs (satisfaction from social media use) in ten life domains. Domain life satisfaction is measured by a single item asking respondents to evaluate their domain life satisfaction in ten corresponding domains. Formative indicators uniquely contribute to the latent construct; thus, they do not necessarily need to covary. Since formative indicators do not need to be correlated, it is not appropriate to conduct the conventional construct 
consistency assessment that relies on common factor analysis (Petter et al., 2007). We followed the procedure suggested by Petter et al. (2007) and Cenfetelli and Bassellier (2009) to assess formative measurement by examining multicollinearity among the indicators, the cooccurrence of negative and positive indicator weights, as well as absolute and relative indicator contributions through their loadings and weights. The lowest and highest variance inflation factor (VIF) are 1.05 and 2.81, which are below the suggested cut-off of 3.3 (Petter et al., 2007). Therefore, we conclude that multicollinearity is not an issue among formative indicators. A few constructs (Community, Health, Consumer, Edu, Social) have co-occurrence of positive and negative indicator weights, which can lead to a misinterpretation of the results. Since these weight indicators are not significant, we decided to remove them. The Self and Leisure constructs have eight and six indicators, respectively. A higher number of indicators may increase the chance of low or non-significant weights. Following Cenfetelli and Bassellier's (2009) suggestion, we tested different groupings of indicators. We found that grouping the Self indicators into two constructs; one construct consisting of indicators associated with self-presentation (Self1 and Self8) and the other consisting of the rest of the indicators associated with self-actualization, resulted in positive weights with a few nonsignificant ones. Since these indicators have significant weights as well as high and significant loadings, we retained them in the structural model estimation. Similarly, we found that grouping the Leisure indicators into two constructs, one construct consisting of indicators associated with relaxation (Leisure1, Leisure4, and Leisure6) and the other construct consisting of indicators associated with entertainment (Leisure2, Leisure3, and Leisure5) resulted in positive weights with a few non-significant ones. Since these indicators have high and significant loadings, we retained them in the structural model estimation. Table A1 in the appendix shows the formative measurement assessment.

The overall life satisfaction is the only reflective construct with multiple indicators in our model. The reliability was evaluated by examining composite reliability (CR). The value of CR (0.92) is higher than the acceptable value of 0.70 , suggesting that reliability is not an issue. Convergent validity was evaluated by examining loadings and average variance extracted (AVE). The highest loading was 0.87 , and the lowest loading was 0.74 , which are higher than the acceptable level of 0.60 . The value of AVE is 0.67 , higher than the acceptable value of 0.50 . See Table A2 in the appendix. Therefore, we conclude that the scale has acceptable convergent validity. Overall, the measurement model demonstrates acceptable validity and reliability.

Data collection from self-report surveys is susceptible to common method bias (Podsakoff et al., 2003). We used two techniques to check potential biases from common method variance. First, we conducted Harman's single-factor test using exploratory factor analysis. Common method bias exists if a single factor is identified from the unrotated factor solution, and the first factor explains the majority of the variance in the variables. In our unrotated factor analysis results, the eigenvalues of seven factors exceed 1.0; the first factor accounted for $41 \%$ of the variance, and the seven factors together accounted for $67 \%$ of the variance. These results suggest that common method bias was not likely to be an issue. Second, we used a marker variable technique (Lindell and Whitney, 2001) by adding marital status as a marker variable. We found that correlations between the study's principal constructs and marital status are from -0.14 and 0.07 , which are low and not significant. We conclude that common method bias was not a major concern for this study. 


\subsection{Structural model}

We evaluated the relationship between social media use and life satisfaction by estimating the influence of satisfaction from social media use on domain life satisfaction and the influence of domain life satisfaction on life satisfaction. Table 7 presents results from the full model (Model 1), the reduced model (Model 2) that removes the non- significant relationships between social media use related to self-presentation (SelfF1) and self domain satisfaction (SelfSat), the reduced model (Model 3) that removes non-significant life domains (i.e., Friend, Self, and Social), and the reduced model with a control variable that is statistically significant (Model $4)$.

\begin{tabular}{|c|c|c|c|c|c|c|c|c|}
\hline & \multicolumn{2}{|c|}{ Model 1} & \multicolumn{2}{|c|}{ Model 2} & \multicolumn{2}{|c|}{ Model 3} & \multicolumn{2}{|c|}{ Model 4} \\
\hline & Path & $\mathbf{R}^{2}$ & Path & $\mathbf{R}^{2}$ & Path & $\mathbf{R}^{2}$ & Path & $\mathbf{R}^{2}$ \\
\hline \multicolumn{9}{|c|}{ Social media use satisfaction $\rightarrow$ Domain satisfaction } \\
\hline Family $\rightarrow$ FamilySat & $0.38^{* * *}$ & 0.15 & $0.38^{* * *}$ & 0.15 & $0.38^{*+*}$ & 0.15 & $0.38^{*+*}$ & 0.15 \\
\hline Friend $\rightarrow$ FriendSat & $0.50^{* * *}$ & 0.25 & $0.50^{* * *}$ & 0.25 & & & & \\
\hline Community $\rightarrow$ CommunitySat & $0.49^{* * *}$ & 0.24 & $0.49^{* * *}$ & 0.24 & $0.49^{* * *}$ & 0.24 & $0.49^{* * *}$ & 0.24 \\
\hline Health $\rightarrow$ HealthSat & $0.35^{s * *}$ & 0.13 & $0.35^{* * *}$ & 0.13 & $0.35^{* * *}$ & 0.13 & $0.35^{*+*}$ & 0.13 \\
\hline Consumer $\rightarrow$ ConsumerSat & $0.48^{* * *}$ & 0.23 & $0.48^{* * *}$ & 0.23 & $0.48^{*+*}$ & 0.23 & $0.48^{* * *}$ & 0.23 \\
\hline Edu $\rightarrow$ EduSat & $0.41^{* * *}$ & 0.17 & $0.41^{* * *}$ & 0.17 & $0.41^{*+*}$ & 0.17 & $0.41^{* * *}$ & 0.17 \\
\hline SelfF1 $\rightarrow$ SelfSat & -0.10 & \multirow[t]{2}{*}{0.17} & & \multirow[t]{2}{*}{0.17} & & & & \\
\hline SelfF2 $\rightarrow$ SelfSat & $0.48^{* * *}$ & & $0.40^{* * *}$ & & & & & \\
\hline LeisureF1 $\rightarrow$ LeisureSat & $0.58^{* * *}$ & \multirow[t]{2}{*}{0.22} & $0.58^{* * *}$ & \multirow[t]{2}{*}{0.22} & $0.58^{*+*}$ & \multirow[t]{2}{*}{0.22} & $0.58^{*+*}$ & \multirow[t]{2}{*}{0.22} \\
\hline LeisureF2 $\rightarrow$ LeisuerSat & $-0.16^{\#}$ & & $-0.16^{\#}$ & & $-0.16^{\#}$ & & $-0.16^{\#}$ & \\
\hline Social $\rightarrow$ SocialSat & $0.28^{* * *}$ & 0.08 & $0.28^{* * *}$ & 0.08 & & & & \\
\hline \multicolumn{9}{|c|}{ Domain satisfaction $\rightarrow$ Life satisfaction } \\
\hline FamilySat $\rightarrow$ LifeSat & $0.23^{* * *}$ & \multirow[t]{9}{*}{0.56} & $0.23^{* * *}$ & \multirow[t]{9}{*}{0.56} & $0.26^{* * *}$ & \multirow[t]{9}{*}{0.55} & $0.28^{* * *}$ & \multirow[t]{11}{*}{0.56} \\
\hline FriendSat $\rightarrow$ LifeSat & -0.05 & & -0.05 & & & & & \\
\hline CommunitySat $\rightarrow$ LifeSat & $0.15^{* *}$ & & $0.15^{* *}$ & & $0.18^{* * *}$ & & $0.18^{*+*}$ & \\
\hline HealthSat $\rightarrow$ LifeSat & $0.11^{*}$ & & $0.11^{*}$ & & $0.13^{*+}$ & & $0.12^{* *}$ & \\
\hline ConsumerSat $\rightarrow$ LifeSat & $0.18^{* * *}$ & & $0.18^{* * *}$ & & $0.18^{* *}$ & & $0.15^{* *}$ & \\
\hline EduSat $\rightarrow$ LifeSat & $0.11^{\#}$ & & $0.11^{\#}$ & & $0.11^{\#}$ & & 0.10 & \\
\hline SelfSat $\rightarrow$ LifeSat & 0.09 & & 0.09 & & & & & \\
\hline LeisureSat $\rightarrow$ LifeSat & $0.09 \#$ & & $0.09^{\#}$ & & $0.12^{*}$ & & $0.11^{*}$ & \\
\hline SocialSat $\rightarrow$ LifeSat & 0.07 & & 0.07 & & & & & \\
\hline \multicolumn{8}{|l|}{ Control variable } & \\
\hline Daily social media use & & & & & & & $0.09^{*}$ & \\
\hline
\end{tabular}

Table 7. Social media use and influence on life satisfaction 


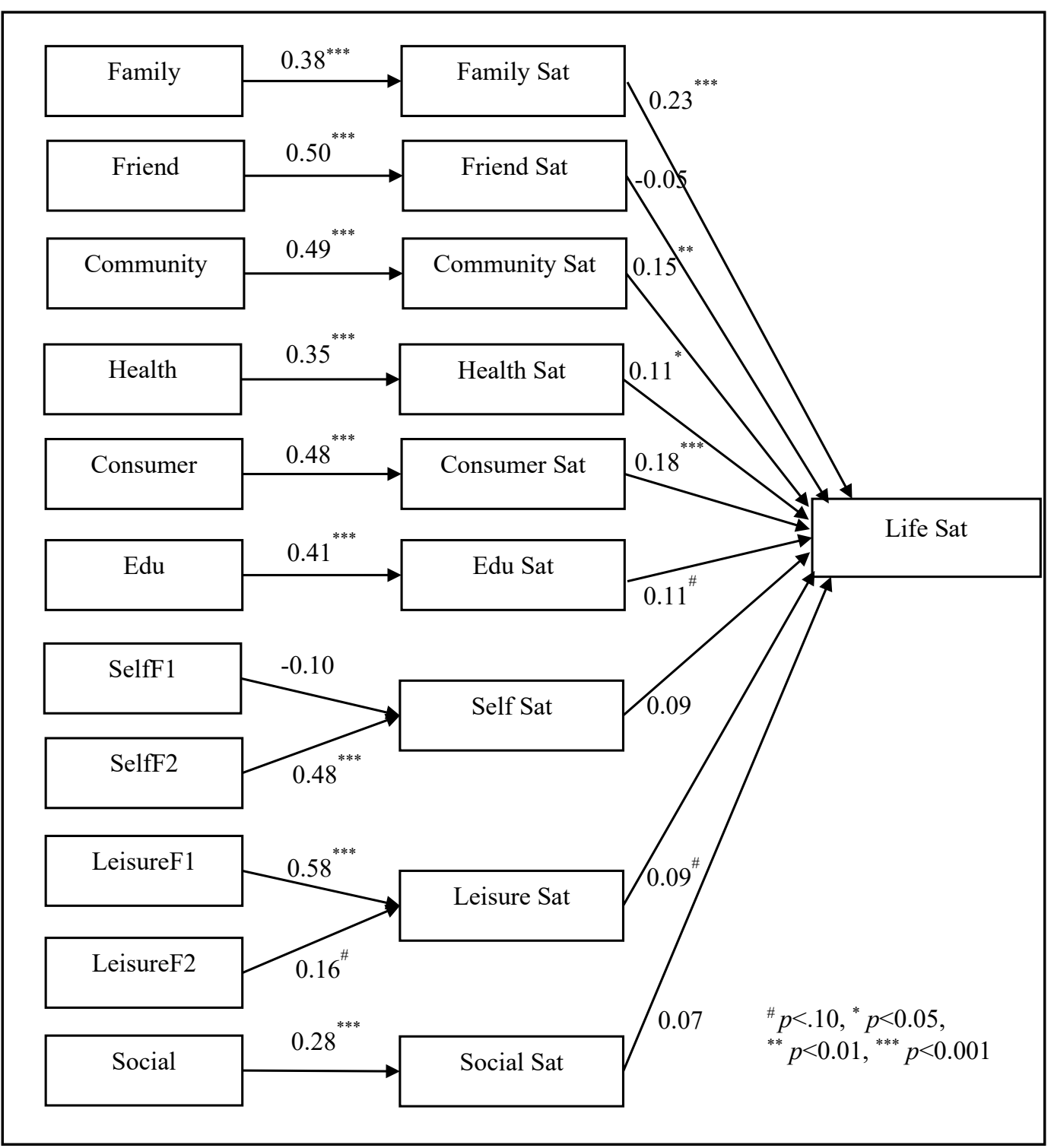

Figure 2. The relationships between social media use and life satisfaction

Figure 2 depicts the structural model and path coefficients. The estimated coefficients are the same for Models 1 and 2. Based on these results, the model explains $56 \%$ of the variance in life satisfaction. Path coefficients for satisfaction from social media use have significant positive effects $(p<.001)$ on domain life satisfaction across all life domains with the exception of two life domains. The effect of satisfaction from social media use for entertainment (LeisureF2) on leisure domain satisfaction (LeisureSat) is negative and weakly significant $(\beta=-0.16, p<.10)$ and the effect of satisfaction from social media use for self-presentation (SelfF1) on self domain satisfaction (SelfSat) is negative and non-significant $(\beta=-0.10, p=\mathrm{ns})$. When examining the estimated path coefficients, we observed the strong influence of satisfaction from social media use on domain life satisfaction in five domains: social media use for relaxation (LeisureF1) on leisure domain satisfaction (LeisureSat) $(\beta=0.58, p<.001)$, social media use for friendship (Friend) on friend domain satisfaction (FriendSat) $(\beta=0.50, p<.001)$, social media use for community purposes (Community) on community domain satisfaction (CommunitySat) ( $\beta=$ $0.49, p<.001$ ), social media use for product and service consumption (Consumer) on consumer domain satisfaction (ConsumerSat) $(\beta=0.48, p<.001)$, and social media use for selfactualization (SelfF2) on self domain satisfaction (SelfSat) $(\beta=0.48, p<.001)$. We observed the 
moderate effects of satisfaction from social media use for learning (Edu) on education domain satisfaction (EduSat) $(\beta=0.41, p<.001)$, social media use to connect with family (Family) on family domain satisfaction (FamilySat) $(\beta=0.38, p<.001)$, social media use for health purposes (Health) on health domain satisfaction (HealthSat) $(\beta=0.35, p<.001)$, and social media use for socialization (Social) on social domain satisfaction (SocialSat) $(\beta=0.28, p<.001$ ).

The effects of domain life satisfaction on the overall life satisfaction (LifeSat) are positive except in the friend domain (FriendSat), which is negative and not significant. In addition, the effects of self domain satisfaction (SelfSat) and social domain satisfaction (SocialSat) are not significant. We removed these non-significant relationships and reported the estimated paths from the reduced model (Model 3). We found that family domain satisfaction (FamilySat) ( $\beta=$ $0.26, p<.001)$ and community domain satisfaction (CommunitySat) $(\beta=0.18, p<.001)$ have strongly significant effects on life satisfaction. Health domain satisfaction (HealthSat) $(\beta=0.13$, $p<.01)$ and consumer domain satisfaction (ConsumerSat) $(\beta=0.18, p<.01)$ have moderately significant effects on life satisfaction. Leisure domain satisfaction $(\beta=0.12, p<.05)$ and education domain satisfaction $(\beta=0.11, p<.10)$ have weakly significant effects on life satisfaction. We tested a number of control variables, including demographic characteristics (age, gender, education, income, marital status), prior social media experience, types of social media applications, and daily social media use duration. We found that only social media use duration has a weakly significant effect in the model $(\beta=0.09, p<.05)$, suggesting that those who spend more time on social media reap more benefits in satisfaction with their lives.

\section{Discussion and conclusion}

This study develops a comprehensive account of older adults' social media use and evaluates the relationship between satisfaction from social media use and life satisfaction. Our findings suggest that social media technology plays an integral role in older adults' lives in multiple life domains. The use of social media has a positive influence on their domain life satisfaction in the family, friend, community, health, consumer, education, self through self-actualization activities, leisure, and social life domains. Among these life domains, family, community, health, consumer, and leisure are identified as salient domains that contribute positively to older adults' life satisfaction in the context of social media use.

Although social media have been used mostly by adolescents and young adults to find new friends, older adults voice their concern about using social media to establish new relationships due to the lack of trust and safety concerns. This is in line with arguments in prior research that older adults have a strong emotional investment with family members and established friends (Chen and Chan, 2011; Hur, 2016). In addition, trust is an important factor affecting information sharing and new relationship development in an online setting, particularly for older adults (Choi et al., 2014).

We believe that discussing older adults' vis-à-vis teens and young adults' social media use gives the insight to understand older adults' motivations to engage with social media. Previous studies reported that teens and young adults use social media mainly for social relationships, entertainment, and self-expression (boyd, 2014; Kross et al., 2013; Oh et al., 2014; Trepte and Reinecke, 2013; Wang et al., 2014). We confirm the general observation in the technology and older adults literature that the needs of older adults as technology users are different from those of young users (Chen and Chan, 2011; Hur, 2016). Our results show that older adults engage with social media for a broader range of motivations: to maintain relationships with 
family and friends, to stay connected and reduce loneliness, to learn new things to keep their mind active and sharp, to share information and connect with others in the community, to seek health-related information, and to engage in activities that promote self-actualization. In contrast to teens and young adults, older adults do not appear to use social media for selfpresentation and entertainment (e.g., following celebrities) to satisfy their self and leisure life domains, respectively. The family, community, health, consumer and leisure for relaxation are salient life domains that contribute to older adults' overall life satisfaction through social media use. Overall, our findings suggest that social media technology has an important role in enhancing older adults' subjective well-being in a digitally enabled society.

\subsection{Implications for research}

This study develops a substantive theory that offers a comprehensive portrayal of older adults' social media use in multiple life domains and explains the linkage between satisfaction from social media use and life satisfaction through domain life satisfaction. The exposition of social media use at an activity level in relation to life domains provides deeper insights to understand the motivations and purposes constructed by older adults to "support typical routines across the multiple contexts of his or her life" (Scheepers and Middleton, 2013, p. 382). Compared with the amount of time spent on social media or the functionality approach that prior research employs to theorize technology use, the fine-grained account of social media use enables us to draw a more accurate inference of the meanings and implications of social media use on older adults' lives. The choice of domain life satisfaction and overall life satisfaction to evaluate the impacts of social media use is pertinent not only for social media but can be used to evaluate the impacts of new technologies that individuals exercise their choice and use their own frames of reference to integrate these technologies into their lives that fit their needs.

This research contributes to the technology use and subjective well-being literature in general and technology use and older adults and social media in particular. Since older adults are usually late adopters of social media, little is known about their social media use and impacts. This research extends the previous conjecture that individuals who use more functionalities of social media are likely to experience more enjoyment (Turel and Serenko, 2012). Our theoretical framework and findings suggest that we need to look beyond the functionalities of social media to examine the context of social media use in order to develop a precise understanding of user engagement with the technology and the impact of social media use on their lives. In contrast to Kross et al. (2013), who reported that social media use undermines young adults' subjective well-being, we found that satisfactory experiences from social media use in several life domains are important to promote older adults' subjective well-being. Our findings are in line with Lelkes (2013) who reported that older adults who use the Internet regularly are less likely to experience social isolation and regular Internet use positively relates to life satisfaction.

This study contributes to advance subjective well-being research. As people across age groups make ICT an integral part of their lives, there is a pressing need to understand whether and to what extent ICT use contributes positively or negatively to individuals' subjective well-being. The results of this study suggest that technology in general and social media, in particular, has an important role to play in enhancing older adults' domain life satisfaction and overall life satisfaction.

From a methodological perspective, this research contributes to IS use and impacts research. The domain of life framework and the mixed methods approach can be applied to study 
individuals' use of social media as well as other malleable technologies. A few studies have employed a similar framework and design to investigate mobile data services use (Choi et al., 2007) and productivity software and Internet use (Techatassanasoontorn and Tanvisuth, 2010). We encourage IS researchers to use a mixed-methods approach to provide rich insights into technology use in which users express their choices to use these technologies to enhance their lives (Scheepers and Middleton, 2013).

\subsection{Implications for practice}

As the aging society is fast approaching and the use of social media is becoming part of everyday life, our work has shown how social media can be used to support older adults in their daily needs and improve their overall life satisfaction. Social activities are important to nurture older adults' well-being (Choi et al., 2014; Dolan et al., 2008). In particular, our findings suggest that social media offers an alternative platform for older adults to keep up with friends, family, community and engage in volunteering activities. It will be helpful if social media platforms take older adults' preferences of social media use into consideration and allow them to customize the interface and interactions to better support their specific needs. In addition, younger generations (e.g., children or grandchildren) may use social media to enhance relationships with older adults in their families, such as participating in their groups, communicating with them on their Facebook wall, and sharing photos with them. These relatively simple activities have the potential to improve older adults' life satisfaction. Governments can also use social media as one of the communication channels to share information with older adults. For example, the Hong Kong social welfare agency uses social media to enhance older adult's well-being. Their goal is to prevent societal issues such as loneliness, abandonment and to improve older adults' healthcare management.

\subsection{Limitations and future research}

This research is subject to a few limitations that offer avenues for future research. We studied older adults' social media use and its impacts in a single country context where data may be predisposed toward one specific culture. Thus, generalizing this study's findings to social media use and life satisfaction of older adults in other countries, whose societies are more individualist and less concerned about family relationships, should be done with caution. In addition, Thailand is one of the countries with a relatively high level of social media adoption across various age groups. Future research may consider conducting a comparative study across multiple countries while providing a rich description of society's extent of social media use to help with an interpretation of the results. The findings shown in this study were a result of a cross-sectional evaluation of satisfaction with social media use and life satisfaction. Thus, limitations on a causal interpretation and implication should be noted. Longitudinal studies to examine how life satisfaction changes over time may add some new understanding of the effectiveness of social media use on life satisfaction.

Aging is a complex process, and this study only scratches the surface of the role of technology in older adults' lives by focusing on chronological age as one dimension of aging. However, chronological age may not fully capture biological, functional, psychological and social dimensions of aging that may impact different individuals in different ways (Chen and Chan, 2011). Some of these age-related factors are functional loss in visual and auditory perception, mobility problems, cognition decline, social isolation, fear of illness, and death, among others. Future research may want to expand the conceptualization of aging to broaden our understanding of the relationship between aging and technology use and impact. 


\section{References}

Andrews, F.M., and Withey, S.B. (1976). Social indicators of well-being: American's perceptions of life quality. Plenum Press, New York, NY.

boyd, d. (2014), It's complicated: The social lives of networked teens, Yale University Press, New Haven, CT.

Campbell, A., Converse, P.E., and Rodgers, W.L. (1976). The quality of American life: Perceptions, evaluations, and satisfactions. Russel Sage Foundation, New York, NY.

Celik, S. S., Celik, Y., Hikmet, N., and Khan, M. M. (2018). Factors affecting life satisfaction of older adults in Turkey. The International Journal of Aging and Human Development, 87(4), 392-414. https://doi.org/10.1177/0091415017740677

Cenfetelli, R.T., and Bassellier, G. (2009). Interpretation of formative measurement in information systems research. MIS Quarterly, 33(4), 689-707. https://doi.org/10.2307/ 20650323

Chang, J.C., and King, W.R. (2005). Measuring the performance of information systems: A functional scorecard. Journal of Management Information Systems, 22(1), 85-115. https://www.jstor.org/stable/40398759

Charness, N., and Boot, W.R. (2009). Aging and information technology use. Current Directions in Psychological Science, 18(5), 253-258. https://doi.org/10.1111\%2Fj.1467-8721.2009.

01647.x

Chen, K., and Chan, A. (2011). A review of technology acceptance by older adults. Gerontechnology, 10(1), 1-12. https://doi.org/10.4017/GT.2011.10.01.006.00

Choi, H., Lee, M., Im, K.S., and Kim, J. (2007). Contribution to quality of life: A new outcome variable for mobile data service. Journal of the Association for Information Systems, 8(12), 598-618. https://doi.org/10.17705/1jais.00146

Choi, J.H., Kim, S., Moon, J.Y., Kang, J., Lee, I., and Kim, J. (2014). Seek or provide: Comparative effects of online information sharing on seniors' quality of life. Communications of the Association for Information Systems, 34, 513-530. https://doi.org/10.17705/1CAIS.03427

Chou, W.S., Hunt, Y.M., Beckjord, E.B., Moser, R.P., and Hesse, B.W. (2009). Social media use in the United States: Implications for health communication. Journal of Medical Internet Research, 11(4), e48. https://dx.doi.org/10.2196\%2Fjmir.1249

Cogburn, D.L., and Espinoza-Vasquez, F.K. (2011). From networked nominee to networked nation: Examining the impact of Web 2.0 and social media on political participation and civic engagement in the 2008 Obama campaign. Journal of Political Marketing, 10(102), 189-213. https://doi.org/10.1080/15377857.2011.540224

Croll, E.J. (2006). The intergenerational contract in the changing Asian family. Oxford Development Studies, 34(4), 473-491. https://doi.org/10.1080/13600810601045833

Diamantopoulos, A. (2011). Incorporating formative measures into covariance-based structural equation models. MIS Quarterly, 35(2), 335-358. https://doi.org/10.2307/ 23044046

Diener, E. (1984). Subjective well-being. Psychological Bulletin, 95(3), 542-575. https://ssrn.com/ abstract $=2162125$

Diener, E., and Diener, M. (1995). Cross-cultural correlates of life satisfaction and self-esteem. Journal of Personality and Social Psychology, 68(4), 653-663. https://psycnet.apa.org/ doi/10.1037/0022-3514.68.4.653 
Diener, E., Emmons, R.A., Larsen, R.J., and Griffin, S. (1985). The satisfaction with life scale. Journal of Personality Assessment, 49(1), 71-75. https://doi.org/10.1207/ s15327752jpa4901_13

Diener, E., Inglehart, R., and Tay, L. (2013). Theory and validity of life satisfaction scales. Social Indicators Research, 112(3), 497-527. https://doi.org/10.1007/s11205-012-0076-y

Diener, E., Suh, E.M., Lucas, R.E., and Smith, H.L. (1999). Subjective well-being: Three decades of progress. Psychological Bulletin, 125(2), 276-302. https://psycnet.apa.org/doi/10.1037/ 0033-2909.125.2.276

Dolan, P., Peasgood, T., and White, M. (2008). Do we really know what makes us happy? A review of the economic literature on the factors associated with subjective well-being. Journal of Economic Psychology, 29(1), 94-122. https://doi.org/10.1016/J.JOEP.2007.09.001

Easterlin, R.A. (2006). Life cycle happiness and its sources: Intersections of psychology, economics, and demography. Journal of Economic Psychology, 27(4), 463-482. https://doi.org/10.1016/j.joep.2006.05.002

ETDA (2020) Thailand Internet user behavior 2020. Available: https://www.etda.or.th/getattachment/c5835c06-e238-4cda-9816814df31caca5/IUB_2020 _Web.pdf.aspx (Accessed June 10 2021).

Gaia, A., Sala, E., and Cerati, C. (2021) Social networking sites use and life satisfaction: A quantitative study on older people living in Europe. European Societies, 23(1), 98-118. https://doi.org/10.1080/14616696.2020.1762910.

Gatto, S.L., and Tak, S.H. (2008). Computer, Internet, and e-mail use among older adults: Benefits and barriers. Educational Gerontology, 34(9), 800-811. https://doi.org/10.1080/ 03601270802243697

Gerow, J.E., Thatcher, J.S., and Grover, V. (2015). Six types of IT-business strategic alignment: An investigation of the constructs and their measurement. European Journal of Information Systems, 24(5), 465-491. https://doi.org/10.1057/ejis.2014.6

Glaser, B.G., and Strauss, A.L. (1967). The discovery of grounded theory: Strategies for qualitative research, Aldine Publishing Company, Chicago, IL.

Hage, E., Wortmann, H., van Offenbeek, M., and Boonstra, A. (2016). The dual impact of online communication on older adults' social connectivity. Information Technology \& People, 29(1), 31-50. https://doi.org/10.1108/ITP-09-2014-0216

Hair, J.F., Hult, G.T.M., Ringle, C., and Sarstedt, M. (2013). A primer on partial least squares structural equation modeling (PLS-SEM), Sage Publications, Thousand Oaks, CA.

Headey, B., Veenhoven, R., and Wearing, A. (1991). Top-down versus bottom-up theories of subjective well-being. Social Indicators Research, 24(1), 81-100. https://doi.org/10.1007/ BF00292652

Hill, R., Beynon-Davies, P., and Williams, M.D. (2008). Older people and Internet engagement: Acknowledging social moderators of Internet adoption, access and use. Information Technology \& People, 21(3), 244-266. https://doi.org/10.1108/09593840810896019

Hur, M.H. (2016). Empowering the elderly population through ICT-based activities. Information Technology \& People, 29(2), 318-333. https://doi.org/10.1108/ITP-03-2015-0052

Jung, Y. (2014). What a smartphone is to me: Understanding user values in using smartphones. Information Systems Journal, 24(4), 299-321. https://doi.org/10.1111/isj.12031

Kahneman, D., and Krueger, A.B. (2006). Developments in the measurement of subjective wellbeing. Journal of Economic Perspectives, 20(1), 3-24. https://doi.org/10.1257/ 089533006776526030 
Kapoor, K.K., Tamilmani, K., Rana, N.P., Patil, P., Dwivedi, Y.K., and Nerur, S. (2018). Advances in social media research: Past, present and future. Information Systems Frontier, 20(3), 531-558. https://doi.org/10.1007/s10796-017-9810-y

Khoo, S.S., and Yang, H. (2020). Social media use improves executive functions in middle-aged and older adults: A structural equation modeling analysis. Computers in Human Behavior, 111, 1-10. https://doi.org/10.1016/j.chb.2020.106388

Kim, C., and Shen, C. (2020). Connecting activities on Social Network Sites and life satisfaction: A comparison of older and younger users. Computers in Human Behavior, 105, 1-8. https://doi.org/10.1016/j.chb.2019.106222

Kross, E., Verduyn, P., Demiralp, E., Park, J., Lee, D.S., Lin, N., Shablack, H., Jonides, J., and Ybarra, O. (2013). Facebook use predicts declines in subjective well-being in young adults. PloS ONE, 8(8). https://doi.org/10.1371/journal.pone.0069841

Lam, J.C.Y., and Lee, M.K.O. (2006). Digital inclusiveness--Longitudinal study of Internet adoption by older adults. Journal of Management Information Systems, 22(4), 177-206.

Leist, A. K. (2013). Social media use of older adults: A mini-review. Gerontology, 59, 378-384. https://www.jstor.org/stable/40398817

Lelkes, O. (2013). Happier and less isolated: Internet use in old age. Journal of Poverty and Social Justice, 21(1), 33-46. https://doi.org/10.1332/175982713X664047

Limayem, M., Gabriele Hirt, S., and Cheung, C.M.K. (2007). How habit limits the predictive power of intention: The case of information systems continuance. MIS Quarterly, 31(4), 705-737. https://doi.org/10.2307/25148817

Lindell, M.K., and Whitney, D.J. (2001). Accounting for common method variance in crosssectional research designs. Journal of Applied Psychology, 86(1), 114-121. https://doi.org/10.1037/0021-9010.86.1.114

Mitzner, T.L., Boron, J.B., Fausset, C.B., Adams, A.E., Charness, N., Czaja, S.J., Dijkstra, K., Fisk, A.D., Rogers, W.A., and Sharit, J. (2010). Older adults talk technology: Technology usage and attitudes. Computers in Human Behavior, 26(6), 1710-1721. https://doi.org/10.1016/j.chb.2010.06.020

Moore, G.C., and Benbasat, I. (1991). Development of an instrument to measure the perceptions of adopting an information technology innovation. Information Systems Research, 2(3), 192-222. https://doi.org/10.1287/isre.2.3.192

Niehaves, B., and Plattfaut, R. (2014). Internet adoption by the elderly: Employing IS technology acceptance theories for understanding the age-related digital divide. European Journal of Information Systems, 23(6), 708-726. https://doi.org/10.1057/ejis.2013.19

Oh, H.J., Ozkaya, E., and LaRose, R. (2014). How does online social networking enhance life satisfaction? The relationships among online supportive interaction, affect, perceived social support, sense of community, and life satisfaction. Computers in Human Behavior, 30(1), 69-78. https://doi.org/10.1016/j.chb.2013.07.053

Oishi, S., Diener, E., Lucas, R.E., and Suh, E.M. (1999). Cross-cultural variations in predictors of life satisfaction: Perspectives from needs and values. Personality and Social Psychology Bulletin, 25(8), 980-990. https://doi.org/10.1177/01461672992511006

Park, N., Kee, K.F., and Valenzuela, S. (2009). Being immersed in social networking environment: Facebook groups, uses and gratifications and social outcomes. Cyberpsychology and Behavior, 12(6), 729-734. https://doi.org/10.1089/cpb.2009.0003

Petter, S., Straub, D., and Rai, A. (2007). Specifying formative constructs in information systems research. MIS Quarterly, 31(4), 623-656. https://doi.org/10.2307/25148814 
Pew Research Center (2021). Social media fact sheets, available at: https://www.pewresearch.org/internet/fact-sheet/social-media/, accessed 10 June 2021.

Podsakoff, P.M., MacKenzie, S.B., Lee, J., and Podsakoff, N.P. (2003). Common method biases in behavioral research: A critical review of the literature and recommended remedies. Journal of Applied Psychology, 88(5), 879-903. https://doi.org/10.1037/0021-9010.88.5.879

Rasmussen, E.E., Punyanunt-Carter, N., LaFreniere, J.R., Norman, M.S., and Kimball, T.G. (2020). The serially mediated relationship between emerging adults' social media use and mental well-being. Computers in Human Behavior, 102, 206-213. https://doi.org/10.1016/j.chb.2019.08.019

Scheepers, R., and Middleton, C. (2013). Personal ICT ensembles and ubiquitous information systems environments: Key issues and research implications. Communications of the Association for Information Systems, 33, 381-392. https://doi.org/10.17705/1CAIS.03322

Selwyn, N. (2004). The information aged: A qualitative study of older adults' use of information and communications technology. Journal of Aging Studies, 18(4), 369-384. https://doi.org/10.1016/j.jaging.2004.06.008

Techatassanasoontorn, A.A., and Tanvisuth, A. (2010). IS Use and quality of Life: A conceptualization and empirical investigation. AIS Transactions on Human-Computer Interaction, 2(2), 26-54. https://doi.org/10.17705/1thci.00013

Thailand PRD (2020). Thailand is preparing for becoming a super-aged society. Available: https://thailand.prd.go.th/mobile_detail.php?cid=4\&nid=10055 (Accessed June 10 2021).

Thomas, D.M., and Watson, R.T. (2002). Q-sorting and MIS research: A primer. Communications of the Association for Information Systems, 8, Article 9. https://doi.org/10.17705/1CAIS.00809

Trentham, B., Sokoloff, S., Tsang, A., \& Neysmith, S. (2015). Social media and senior citizen advocacy: An inclusive tool to resist ageism? Politics, Groups, and Identities, 3(3), 558-571. https://doi.org/10.1080/21565503.2015.1050411

Trepte, S., and Reinecke, L. (2013). The reciprocal effects of social network site use and the disposition for self-disclosure: A longitudinal study. Computers in Human Behavior, 29(3), 1102-1112. https://doi.org/10.1016/j.chb.2012.10.002

Turel, O., and Serenko, A. (2012). The benefits and dangers of enjoyment with social networking websites. European Journal of Information Systems, 21(5), 512-528. https://doi.org/10.1057/ejis.2012.1

Urquhart, C., Lehmann, H., and Myers, M.D. (2010). Putting the 'theory' back into grounded theory: Guidelines for grounded theory studies in information systems. Information Systems Journal, 20(4), 357-381. https://doi.org/10.1111/j.1365-2575.2009.00328.x

United Nations (2015) World Population Ageing: 2015, available at: https://www.un.org/en/development/desa/population/publications/pdf/ageing/WPA20 15_Highlights.pdf, accessed 10 June 2021.

United Nations (2017) World Population Ageing 2017, available at: https://www.un.org/en/development/desa/population/publications/pdf/ageing/WPA20 17_Highlights.pdf, accessed 10 June 2021.

Valenzuela, S., Park, N., and Kee, K.F. (2009). Is there social capital in a social network site?: A Facebook use and college students' life satisfaction, trust, and participation. Journal of Computer-Mediated Communication, 14(4), 875-901. https://doi.org/10.1111/j.10836101.2009.01474.x 
van Praag, B.M.S., Frijters, P., and Ferrer-i-Carbonell, A. (2003). The anatomy of subjective well-being. Journal of Economic Behavior $\mathcal{E}$ Organization, 51(1), 29-49. https://doi.org/10.1016/S0167-2681(02)00140-3

Venkatesh, V., Brown, S.A., and Bala, H. (2013). Bridging the qualitative-quantitative divide: Guidelines for conducting mixed methods research in information systems. MIS Quarterly, 37(1), 21-54. https://doi.org/10.25300/MISQ/2013/37.1.02

Verdegem, P. (2011). Social media for digital and social inclusion: Challenges for information society 2.0 research \& policies. tripleC, 9(1), 28-38. https://doi.org/10.31269/triplec. v9i1.225

Wang, J., Jackson, L.A., Gaskin, J., and Wang, H. (2014). The effects of social networking site (SNS) use on college students' friendship and well-being. Computers in Human Behavior, 37, 229-236. https://doi.org/10.1016/j.chb.2014.04.051

WHO (2018) Ageing and health, available at https://www.who.int/news-room/factsheets/detail/ageing-and-health, accessed 3 June 2021.

$\mathrm{Xu}$, C., Ryan, S., Prybutok, V., and Wen, C. (2012). It is not for fun: An examination of social networking site usage. Faculty Research \& Creative Activity, 7, https://thekeep.eiu.edu/ business_fac/7.

Xu, X., Zhao, Y. C., and Zhu, Q. (2020). The effect of social media use on older adults' loneliness: The moderating role of self-disclosure. In International Conference on HumanComputer Interaction (pp. 131-145). Springer.

\section{Appendix: Measurement model assessment}

Table A1. Formative indicators

\begin{tabular}{|c|c|c|c|c|c|}
\hline Construct & Item & Weight & t-stat & Loading & t-stat \\
\hline \multirow[t]{4}{*}{ Family } & Family1 & 0.47 & $2.29^{\circ}$ & 0.82 & $8.58^{\cdots *}$ \\
\hline & Family2 & 0.26 & $2.93^{* *}$ & 0.43 & $3.99 \cdots$ \\
\hline & Family3 & 0.25 & 1.44 & 0.54 & $4.23^{\cdots *}$ \\
\hline & Family4 & 0.44 & $1.77^{\sharp}$ & 0.84 & $8.26 \cdots$ \\
\hline \multirow[t]{5}{*}{ Friend } & Friend1 & 0.22 & $1.71^{\#}$ & 0.74 & $10.15^{\cdots}$ \\
\hline & Friend2 & 0.25 & 1.57 & 0.77 & $9.61^{\cdots *}$ \\
\hline & Friend3 & 0.12 & 0.75 & 0.69 & $8.37^{\cdots+}$ \\
\hline & Friend4 & 0.54 & $3.55^{\cdots *}$ & 0.92 & $20.81^{\cdots}$ \\
\hline & Friend5 & 0.10 & 0.62 & 0.75 & $10.46^{\cdots+}$ \\
\hline \multirow[t]{4}{*}{ Community } & Community2 & 0.14 & 0.74 & 0.38 & $3.91^{\cdots}$ \\
\hline & Community3 & 0.56 & $3.46^{\cdots}$ & 0.89 & $13.82^{\cdots}$ \\
\hline & Community4 & 0.22 & 1.21 & 0.75 & $8.17^{\cdots+\cdots}$ \\
\hline & Community5 & 0.37 & $2.28^{* \prime}$ & 0.77 & $8.69 \cdots$ \\
\hline \multirow[t]{3}{*}{ Health } & Health2 & 0.47 & $2.50^{*}$ & 0.79 & $7.61^{\cdots}$ \\
\hline & Health3 & 0.61 & $4.29^{\cdots \cdots}$ & 0.84 & $9.88^{\cdots \cdots}$ \\
\hline & Health4 & 0.17 & 0.89 & 0.70 & $6.07^{\cdots \cdot}$ \\
\hline Consumer & Consumer1 & 0.46 & $3.71^{\cdots}$ & 0.80 & $10.18^{\cdots}$ \\
\hline
\end{tabular}




\begin{tabular}{|c|c|c|c|c|c|}
\hline & Consumer3 & 0.35 & $2.82^{* *}$ & 0.64 & $6.27^{* * *}$ \\
\hline & Consumer4 & 0.50 & $4.47^{\ldots *}$ & 0.82 & $12.50^{\mu * *}$ \\
\hline \multirow[t]{2}{*}{ Edu } & Edu1 & 0.44 & $3.14^{* *}$ & 0.77 & $8.31^{* * *}$ \\
\hline & Edu3 & 0.72 & $6.33^{\cdots *}$ & 0.92 & $18.28^{\ldots+*}$ \\
\hline \multirow[t]{2}{*}{ SelfF1 } & Self1 & 0.40 & $2.01^{\circ}$ & 0.69 & $4.62^{* * *}$ \\
\hline & Self8 & 0.78 & $5.28^{\ldots *}$ & 0.93 & $12.69^{\ldots+*}$ \\
\hline \multirow[t]{6}{*}{ SelfF2 } & Self2 & 0.18 & 1.24 & 0.69 & $7.33^{\cdots *}$ \\
\hline & Self3 & 0.14 & 0.74 & 0.59 & $5.08^{* * *}$ \\
\hline & Self4 & 0.41 & $2.71^{* *}$ & 0.80 & $9.85^{* * *}$ \\
\hline & Self5 & 0.22 & 1.37 & 0.72 & $7.34^{* * *}$ \\
\hline & Self6 & 0.17 & 0.85 & 0.69 & $7.04^{* * *}$ \\
\hline & Self7 & 0.26 & $1.67^{\#}$ & 0.72 & $7.21^{* * *}$ \\
\hline \multirow[t]{3}{*}{ LeisureF1 } & Leisure1 & 0.19 & 1.36 & 0.53 & $4.50^{\ldots * *}$ \\
\hline & Leisure4 & 0.34 & $2.94^{* *}$ & 0.65 & $6.58^{\ldots * *}$ \\
\hline & Leisure6 & 0.74 & $7.01^{* * *}$ & 0.91 & $17.84^{+* *}$ \\
\hline \multirow[t]{3}{*}{ LeisureF2 } & Leisure2 & 0.24 & 1.10 & 0.71 & $4.49^{* * *}$ \\
\hline & Leisure3 & 0.51 & $2.45^{*}$ & 0.85 & $7.53^{* * *}$ \\
\hline & Leisure5 & 0.48 & $2.13^{*}$ & 0.82 & $6.43^{\cdots * *}$ \\
\hline \multirow[t]{2}{*}{ Social } & Social2 & 0.83 & $4.72^{* *}$ & 0.98 & $18.31^{* * *}$ \\
\hline & Social3 & 0.26 & 1.09 & 0.72 & $4.80^{2 * * *}$ \\
\hline
\end{tabular}

Note: Work2, Community1, Health1, Consumer1, Edu2, and Social1 have negative weights. Since all of these weights are not significant in our sample, we decide to remove them. The Work construct only has two indicators, and the removal of Work2 results in a single indicator for this construct. Since more than $70 \%$ of respondents are retirees, we decided to drop this construct from the model. For the Self construct, Self1 and Self8 have negative weights. For the Leisure constructs, Leisure2, Leisure3, and Leisure5 have negative weights. We created two separate formative constructs, SelfF1 consisting of Self1 and Self8 and SelfF2 consisting of the rest of the indicators. Similarly, we created two separate formative constructs, LeisureF1 consisting of Leisure1, Leisure4, and Leisure6 and LeisureF2, consisting of Leisure2, Leisure3, and Leisure5. We reran the measurement model and these Self and Leisure indicators show positive weights. We retain these indicators for structural model assessment.

Table A2. Reflective indicators

\begin{tabular}{|l|l|l|l|l|}
\hline Item & Mean & Std. Dev. & Loading & t-stat \\
\hline LifeSat1 & 5.57 & 1.07 & 0.81 & $28.60^{* * *}$ \\
\hline LifeSat2 & 5.69 & 0.98 & 0.87 & $51.46^{* * *}$ \\
\hline LifeSat3 & 5.93 & 1.00 & 0.86 & $40.12^{\cdots *}$ \\
\hline LifeSat4 & 5.81 & 1.10 & 0.87 & $51.32^{* * *}$ \\
\hline LifeSat5 & 5.38 & 1.30 & 0.74 & $24.51^{* * *}$ \\
\hline$\# p<.10^{*} p<0.05,{ }^{* *} p<0.01,{ }^{* * *} p<0.001$ & \\
\hline
\end{tabular}


Copyright: (c) 2022 authors. This is an open-access article distributed under the terms of the Creative Commons Attribution-NonCommercial 3.0 Australia License, which permits noncommercial use, distribution, and reproduction in any medium, provided the original author and AJIS are credited.

doi: https://doi.org/10.3127/ajis.v26i0.3269

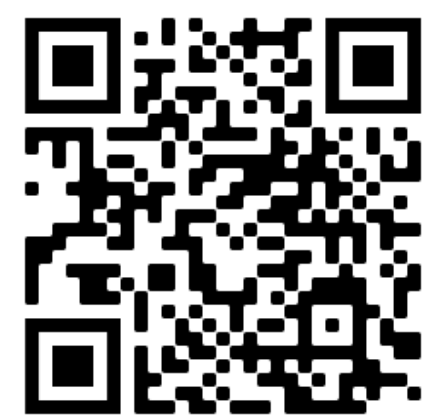

